\title{
The impact of human capital on labour productivity in manufacturing sectors of the European Union
}

Citation for published version (APA):

Cörvers, F. (1996). The impact of human capital on labour productivity in manufacturing sectors of the European Union. Researchcentrum voor Onderwijs en Arbeidsmarkt, Faculteit der Economische Wetenschappen. ROA Research Memoranda No. 2E https://doi.org/10.26481/umaror.199602E

Document status and date:

Published: 01/01/1996

DOI:

10.26481/umaror.199602E

Document Version:

Publisher's PDF, also known as Version of record

\section{Please check the document version of this publication:}

- A submitted manuscript is the version of the article upon submission and before peer-review. There can be important differences between the submitted version and the official published version of record. People interested in the research are advised to contact the author for the final version of the publication, or visit the DOI to the publisher's website.

- The final author version and the galley proof are versions of the publication after peer review.

- The final published version features the final layout of the paper including the volume, issue and page numbers.

Link to publication

\footnotetext{
General rights rights.

- You may freely distribute the URL identifying the publication in the public portal. please follow below link for the End User Agreement:

www.umlib.nl/taverne-license

Take down policy

If you believe that this document breaches copyright please contact us at:

repository@maastrichtuniversity.nl

providing details and we will investigate your claim.
}

Copyright and moral rights for the publications made accessible in the public portal are retained by the authors and/or other copyright owners and it is a condition of accessing publications that users recognise and abide by the legal requirements associated with these

- Users may download and print one copy of any publication from the public portal for the purpose of private study or research.

- You may not further distribute the material or use it for any profit-making activity or commercial gain

If the publication is distributed under the terms of Article $25 \mathrm{fa}$ of the Dutch Copyright Act, indicated by the "Taverne" license above, 
The impact of human capital on labour productivity in manufacturing sectors of the European Union

Frank Cörvers

ROA-RM-1996/2E

Research Centre for Education and the Labour Market

Faculty of Economics and Business Administration

University of Limburg

Maastricht, February 1996 


\section{CIP-GEGEVENS KONINKLIJKE BIBLIOTHEEK, DEN HAAG}

Cörvers, Frank

The impact of human capital on labour productivity in manufacturing sectors of the European Union/ Frank Cörvers. - Maastricht: Research Centre for Education and the Labour Market, Faculty of Economics and Business Administration, University of Limburg. (ROA-RM-1996/2E)

Met lit. opg.

ISBN 90-5321-169-1 
Trefw.: arbeidsproduktiviteit; industrieën; Europese Unie/human capital.

\section{Contents}

Page

Abstract

1 Introduction 1

2 Outline of the model 3

3 Data overview $\quad 7$

4 Estimation results 9

5 Conclusions 14

$\begin{array}{ll}\text { References } & 15\end{array}$

$\begin{array}{ll}\text { Data Appendix } & 17\end{array}$ 


\begin{abstract}
This paper discusses the effects of human capital on both the level and growth of labour productivity in manufacturing sectors in seven Member States of the European Union. Sectoral labour productivity is regarded as a measure of international competitiveness. Human capital is represented by the shares of intermediate and highly-skilled workers in the work force of a sector. The paper shows that the manufacturing sectors can be divided into three classes of sectors: low-skill, medium-skill and high-skill sectors. The estimation results show that both intermediate and highly-skilled labour have a positive effect on the sectoral labour productivity level, although the effect is only significant for highly-skilled labour. Moreover, there are indications of underinvestment of human capital in some manufacturing sectors. These sectors could improve their competitive position by raising the employment shares of intermediate and highly-skilled labour. Finally, intermediateskilled labour has a significantly positive effect on the growth in sectoral labour productivity.

I would like to thank Andries de Grip, Hans Heijke and Lex Borghans for their helpful suggestions. I would like to thank Jeroen Hoevenberg, Hans van Hooff, Niels Langkjar, Maureen Slabbers and Bart Verspagen for their assistance and suggestions in collecting and processing the data. All mistakes and the views expressed remain my own responsibility.
\end{abstract}




\section{Introduction}

Many recent publications in economic literature on export performance seem to reflect the worries of governments about the strength of their countries' international competitiveness. ${ }^{1}$ However, there is no general agreement on how competitiveness ought to be defined. Definitions of competitiveness are based on a variety of indicators such as labour productivity, cost advantages, product quality, or export/import ratios (see Francis and Tharakan, 1989; Niosi, 1991). This paper asks whether the factor input of human capital at sector level matters for the international competitiveness of manufacturing sectors in seven Member States ${ }^{2}$ of the European Union. Human capital is here regarded as an important source of international competitiveness, because human capital is supposed to increase the productivity of workers. Therefore the paper regards labour productivity as the indicator of international competitiveness. ${ }^{3}$ The input of human capital is represented by the proportions of intermediate and highly-skilled workers in the work force of a sector, whereas the sectoral labour productivity is represented by the value added per worker.

Cörvers (1994) discusses four effects of human capital on labour productivity: the 'worker effect', the 'allocative effect', the 'diffusion effect' and the 'research effect'. ${ }^{4}$ This paper will argue that the first and second of these effects underpin the relevance of human capital for the productivity level, whereas the latter two effects underpin the relevance of human capital for productivity growth.

The first of these, the worker effect (or 'own productivity' effect) has been explained by Welch (1970). He assumes that firms produce only one good with the production factor education, and that other resources are given. The worker effect refers to the positive marginal productivity of education with respect to that particular good. Workers with a higher level of education are assumed to be more efficient in working with the resources at hand, i.e. these workers produce more physical output. In other words, education increases the effective labour input from the hours worked. Therefore a better educated labour force shifts the production possibility curve outwards. According to Welch (1970, p. 43) the worker effect is presumably "related to the complexity of the physical production process."

1. See for example Francis and Tharakan (1989), Porter (1990) and the White Paper of the European Commission (1994).

2. Belgium, Germany, Denmark, Spain, France, Great Britain and the Netherlands are included. For data reasons, other countries are excluded.

3. Moreover, according to the Ricardian theory of international trade, labour productivity is an important determinant of trade between countries. See e.g. MacDougall (1951), Balassa (1963) and Dornbush, Fisher and Samuelson (1977).

4. These effects are based upon the studies of Nelson and Phelps (1966), Welch (1970), Ram (1980) and Pencavel (1991), inter alia. For a discussion of the empirical evidence on these effects, see also Cörvers (1994) and Cörvers, De Grip and Orbon (1995). 
The more complex the production technique is, the more 'room' is left for the worker effect to improve the (technical) efficiency of production. An increase in the proportion of intermediate or highly-skilled workers, relative to low-skilled workers, can increase the productivity level in physical units.

Second, the allocative effect points to the greater (allocative) efficiency of better educated workers in allocating all input factors to the production process (including education itself) between the alternative uses. Welch (1970) gives two examples of the allocative effect. If there is one fixed input factor to produce two goods (or varieties), education may improve the total revenues of firms by means of a better allocation of the input factor between the alternative outputs. Although the production process is technically efficient because the firm produces on the production possibility curve (expressed in physical units), workers have more knowledge of how to maximize the marginal value product (expressed in money units) of the input factor. Total revenues are maximized if the marginal value product of the input factor is equalized for all goods. Another allocative effect is present if, in addition to education as an input factor, two (or more) other inputs are included in the production function. If just one good is produced with two inputs, education may also help to select the efficient quantities of inputs. In equilibrium the marginal value product of the inputs should equal the price of the inputs. In fact, education seems to provide the skills to make better decisions based upon the available information. ${ }^{5}$ As a result of the allocative effect, an increase in the relative proportions of intermediate and highly-skilled is expected to lead to a higher productivity level in money units.

Third, the diffusion effect stresses that better educated workers are more able to adapt to technological change and will introduce new production techniques more quickly. Nelson and Phelps (1966) state that "educated people make good innovators, so that education speeds the process of technological diffusion" (see also Bartel and Lichtenberg, 1987). Moreover, Nelson and Phelps (1966) stress the role of receiving, decoding and understanding information in performing a job. ${ }^{6}$ A higher level of education increases the ability to discriminate between more and less profitable innovations and reduces the uncertainty about investment decisions with regard to new processes and products. Therefore education increases the probability of successful and early adoption of innovations. Higher proportions of intermediate and highly-skilled workers, relative to lowskilled workers, would be expected to lead to more rapid and successful adoption of innovations and higher productivity growth.

Fourth, the research effect refers to the role of higher education as an important input factor in research and development $(R \& D)$ activities. $R \& D$, in turn, is a key factor for

5. See also Ram (1980, p. 366): "Education generally has the effect of lowering the (marginal) costs of acquiring production-related information, and of raising the (marginal) benefits of such information."

6. In fact the diffusion effect can be regarded as a special case of the allocation effect (see Welch, 1970). 
technological progress and productivity growth (see, e.g., the endogenous growth models in Romer, 1990 and Grossman and Helpman, 1992). Since R\&D activities are very complex, ${ }^{7}$ a relatively large proportion of intermediate and highly-skilled workers is a prerequisite to increase technological knowledge and achieve productivity growth (see also Englander and Gurney, 1994).

This paper analyses the effects of the employment shares of intermediate and highlyskilled workers per sector on both the sectoral productivity level and the sectoral productivity growth. The empirical analysis is applied to fifteen manufacturing sectors in seven countries of the European Union. Since the labour productivity of a sector is a measure of competitiveness, an increase in the employment shares of intermediate and highly-skilled workers may improve the competitive position of manufacturing sectors. If the employment shares of intermediate and highly-skilled labour are either too small or too large relative to the effects on sectoral labour productivity, this may point to underinvestment or overinvestment of human capital. Other variables included in the analysis are capital intensity and average firm size in the sector.

The next section of the paper discusses the model that allows for the effects of different human capital inputs on labour productivity at the sector level. Section 3 outlines the data concerning the employment shares of intermediate and highly-skilled labour across the manufacturing sectors of the European Union between 1988 and 1991. Section 4 reports on the results of the empirical analysis. Finally, section 5 presents some conclusions.

\section{Outline of the model}

This section aims to develop a model which allows for the four effects of human capital, which have been mentioned above, on the labour productivity of sectors. First, a model is developed which allows for the worker and the allocative effect of intermediate and highlyskilled labour on the productivity level of a sector. Next, the model is adjusted to estimate the diffusion and the research effect of intermediate and highly-skilled labour on the productivity growth of a sector.

Suppose that firm $i$ produces net output $Y_{i}$ according to the Cobb-Douglas production function of equation (1) with $L_{i}$ units of labour and $K_{i}$ units of physical capital, and that the efficiency parameter $A$ is given. Moreover, $\alpha 1$ and $\beta 2$ represent the output elasticities of physical capital and labour, respectively.

$$
Y_{i}=A K_{i}^{\alpha} L_{i}^{\beta} 3
$$

7. Notice that the research effect is similar to the worker effect in that both are related to the complexity of the production process. 
The average labour productivity of a sector can be found by aggregation of $N$ firms of the sector, assuming equal firm sizes (i.e. $\bar{Y}=Y_{i}, \bar{K}=K_{i}, \bar{L}=L_{i} 4$, see Davies and Caves, 1987).

$$
\frac{Y}{L}=\frac{N \bar{Y}}{N \bar{L}}=\frac{N A \bar{K}^{\alpha} \bar{L}^{\beta}}{N \bar{L}}=A\left(\frac{K}{L}\right)^{\alpha} \bar{L}^{\alpha+\beta-1} 5
$$

Equation (2) shows that the labour productivity of a sector depends on the efficiency parameter, the sector's capital intensity (which equals the capital intensity of a firm) and the average firm size. From equation (2) it follows that if constant returns to scale holds, the average firm size plays no role $($ since $\alpha+\beta=16){ }^{8}$

The $L$ units of labour in a sector can be corrected for the inputs of human capital. This results in the effective labour input $L^{\prime}$, which may allow for the various characteristics of workers with regard to their human capital, including the years of initial schooling, participation in training courses, years of experience and tenure, etc. There are various ways to find the effective labour input (see e.g. Fallon, 1987). ${ }^{9}$ Here the effective labour input $L^{\prime}$ is represented by a Cobb-Douglas function with the employment shares of low, intermediate and highly-skilled labour ( $L S, I S$ and $H S$, respectively) as the input variables. ${ }^{10}$ The employment shares of intermediate and highly-skilled workers per sector are used as an approximation for the input of human capital. ${ }^{11}$

The following Cobb-Douglas form of effective labour input will be used.

$L^{\prime}=L^{*} L S^{\theta_{L}} I S^{\theta_{I}} H S^{\theta_{H}} 7$

Correcting equation (2) for effective labour input according to the above equation, substituting

$L S$ for (1! IS! HS) and assuming that $\theta_{L}=1-\theta_{I}-\theta_{H} 8$ results in the following equation:

8. If firms are not equal in size, the average firm size of a sector differs (see Davies and Caves, 1987).

9. The major disadvantage of the approach of aggregating human capital inputs is that it is assumed that the separability assumption holds, i.e., the assumption that the levels of nonlabour inputs, such as physical capital, have no impact on the relative marginal productivities of the human capital inputs (see, e.g., Fallon, 1987 and Cörvers, 1994).

10. See Bowles (1970) for aggregating by a CES function and Davies and Caves (1987) for aggregating by a linear function.

11. Other human capital inputs which have been mentioned previously (see also Cörvers, 1994) are not incorporated in this study. These human capital inputs can easily be incorporated if data on aspects such as training intensity is available. 


$$
\frac{Y}{L}=A\left(\frac{K}{L}\right)^{\alpha} \bar{L}^{\alpha+\beta-1}(1-I S-H S)^{\beta\left(1-\theta_{I}-\theta_{H}\right)} I S^{\beta \theta_{I}} H S^{\beta \theta_{H}} 9
$$

Taking the logarithm of both sides results in equation.

$\ln \frac{Y}{L}=\ln A+\alpha \ln \frac{K}{L}+(\alpha+\beta-1) \ln \bar{L}+\beta\left(1-\theta_{I}-\theta_{H}\right) \ln (1-I S-H S)+\beta \theta_{I} \ln I S+\beta \theta_{H} \ln H S 10(5)$

The above equation is appropriate to estimate the effects of human capital on the productivity level of sectors. These effects are represented by the coefficients th 11 and th 12 of intermediate-skilled and highly-skilled labour, respectively. If net output is measured in values instead of volumes, as in this paper, the worker effect and the allocative effect cannot be distinguished from each other (see also Welch, 1970). As stated before, the worker effect of human capital increases net output per worker due to a larger net output in physical units, whereas the allocative effect leads to a larger net output in money units. The coefficients th 13 and th 14 are equal to zero if human capital, represented by the employment shares of intermediate and highly-skilled workers, does not have a combined worker and allocative effect on sectoral labour productivity.

The elasticity of sectoral labour productivity with respect to highly-skilled labour, which equals the output elasticity of highly-skilled labour, is found by differentiating equation (5) to the logarithm of $H S^{12}$

$$
\frac{d \ln (Y / L)}{d \ln H S}=\frac{d(Y / L)}{d H S} \frac{H S}{Y / L}=\beta \frac{\theta_{H}(1-I S)-H S\left(1-\theta_{I}\right)}{(1-I S-H S)} 15
$$

It follows that the output elasticities of both intermediate-skilled and highly-skilled labour are positive as long as $\theta_{H}>H S 16$ and $\theta_{I}>I S 17$. Notice that the marginal productivities of highly-skilled labour, $d(Y / L) / d H S$ 18, and intermediate-skilled labour, $d(Y / L) / d I S 19$, are zero if the sectoral labour productivity is maximized. Thus, in the Cobb-Douglas form of the effective labour input, there are opportunities for increasing the labour productivity of a sector if the effect ${ }^{13}$ of highly-skilled (or intermediate-skilled) labour on the sectoral labour productivity is larger than the employment share of highly-skilled (or intermediate-skilled) labour. However, the neoclassical theory of production assumes profit maximization rather than the maximization of labour productivity. To maximize profits with perfectly competitive labour and product markets, the marginal productivities of intermediate and highly-skilled workers have to be equal to the respective real wages. ${ }^{14}$ Therefore the marginal

12. Differentiation to the logarithm of IS leads to a similar result.

13. As has been argued above, this effect consists of both the worker and the allocative effect.

14. If firms have monopsonistic power on the labour market and/or monopolistic power in the product market, the marginal productivity exceeds the real wage (see e.g. Cörvers, 1994, and Hartog, 1992). 
productivities of both intermediate and highly-skilled labour should be positive, which implies that $\theta_{H}>H S 20$ and $\theta_{I}>I S 21$ in case of profit maximization.

Next, the diffusion and the research effect on the productivity growth of a sector are incorporated in the model. The two effects can be highlighted by assuming that the efficiency parameter $A$, which indicates the level of technology actually employed in production (Nelson and Phelps, 1966), is the only factor which varies over time (represented by $t$ ), i.e. the growth rates of the factor inputs of physical capital and intermediate and highly-skilled labour are assumed to be zero. The efficiency parameter can be modelled as follows (see e.g. Nelson and Phelps, 1966).

$A(t)=A_{0} e^{g t} 22$

In the above equation, $g$ represents the rate of increase in the efficiency parameter. The next equation is obtained by substituting equation (7) into (5), differentiating the resulting equation with respect to $t$ and rewriting the result to solve for $g$.

$$
g=\frac{d \frac{Y}{L}(t) / d t}{\frac{Y}{L}}=\frac{d A(t) / d t}{A(t)} 23
$$

It follows that the productivity of a sector also increases at growth rate $g .{ }^{15}$ If the diffusion and research effect of human capital are to be incorporated into the last equation, the growth in sectoral productivity has to be dependent on the employment share of both intermediate and highly-skilled workers. Nelson and Phelps (1966) state that the diffusion of technological knowledge depends on the product of the gap between the level of available technology $T(t)$ and the level of technology in practice $A(t)$ on the one hand, and the human capital intensity of production on the other. The technological gap, which is represented by $G A P$, can be defined as $(T(t) ! A(t)) / A(t) .{ }^{16}$ Therefore this paper defines the diffusion effect as $I S^{\star} G A P$ and $H S^{*} G A P$, for the diffusion of technological knowledge by intermediate and highly-skilled labour, respectively. Moreover, sectoral productivity levels may converge, or diverge, for reasons other than the diffusion effect (see Verspagen, 1992). Therefore the technological gap is included in the subsequent analysis as an independent variable to explain productivity growth. Furthermore, the research effect points to the relevance of the employment shares of both intermediate and highly-skilled labour

15. Again, this result only holds if the inputs of physical and human capital do not change over time. However, the growth of the capital intensity, $d(K / L) / d t$ and the growth of the employment shares of intermediate skilled labour, $d(I S) / d t$, and highly-skilled labour, $d(H S) / d t$, are incorporated into the empirical analysis of section 4.

16. See section 4 and the data appendix for a description of how the level of available technology, the level of technology incorporated in production and the technological gap are actually measured. 
for productivity growth. Although only a proportion of the intermediate and highly-skilled workers are employed in R\&D-activities, it is assumed that the productivity growth of a sector is linearly dependent on the employment shares of both intermediate and highlyskilled labour. Explaining the productivity growth of a sector by the diffusion and the research effect results in the following equation.

$$
g=\gamma_{R I} I S+\gamma_{R H} H S+\gamma_{D I} I S * G A P+\gamma_{D H} H S * G A P+\gamma_{G} * G A P 24
$$

The diffusion effect of intermediate and highly-skilled workers is represented by ga 25 and ga 26, respectively. Moreover, the research effect of intermediate and highly-skilled workers is represented by $g a 27$ and $g a 28$. Finally, ga 29 indicates the extent to which the technological gap leads to a convergence or divergence of sectoral productivity. The above equation is appropriate for estimating the diffusion and research effect on the productivity growth of sectors.

\section{Data overview}

This section presents the employment shares of intermediate and highly-skilled workers, which will be used for the regression analysis in the next section. It begins with a ranking of the employment shares of intermediate and highly-skilled labour for the fifteen manufacturing sectors of each country in the sample, followed by a discussion of the level and the growth of the employment shares in each country in the period 1988 to $1991 .{ }^{17}$

The data appendix shows the employment shares of intermediate and highly-skilled workers per sector for seven countries of the European Union in 1988. For each country, the sectors are ranked according to the employment share of highly-skilled workers. Ranking the sectors according to the employment share of intermediate-skilled workers would result in a rank order of sectors that is less similar across countries. The following high-skill sectors were selected from the sector rank orders: chemicals (che), electrical machinery (ele), instruments (opt) and machinery (mac). The cross-country average ${ }^{18}$ employment share of highly-skilled workers in the high-skill sectors is at least 0.15 , and the average employment share of low-skilled workers in the high-skill sectors is never greater than 0.50 . In addition to this, it is possible to identify four medium-skill sectors: petroleum (pet), transport (tra), paper (pap) and basic metals (bmi). In the medium-skill sectors the cross-country average employment share of highly-skilled workers is between 0.10 and 0.15 , and the average employment share of low-skilled workers is between 0.50 and 0.60 . The remaining sectors are termed the 'low skill' sectors. In these sectors the average employment share of highly-skilled workers is smaller than 0.10 , and the average

17. See the appendix for the data sources.

18. For each manufacturing sector, the average employment share is found by calculating the unweighted mean of the seven countries in the sample. 
employment share of low-skilled workers is larger than $0.60 .^{19}$

However, two points should be noticed with regard to the classification of sectors by their skill intensity. Firstly, some sectors of a particular country are not ranked according to the above classification. The rank order of low-skill, medium-skill and high-skill sectors fits perfectly well for Spain and France. However, in Belgium the medium-skill transport sector (tra) has a small employment share of highly-skilled workers, whereas the low-skill food (foo) and rubber and plastic (rup) sectors have large employment shares of highly-skilled workers. In Germany the medium-skill basic metals sector (bmi) has a small employment share of highly-skilled workers. On the other hand, the low-skill wood sector (woo) and other manufacturing industries (oma) have large employment shares of highly-skilled workers. In Denmark the medium-skill basic metal (bmi) and petroleum (pet) sectors have large employment shares of highly-skilled workers, whereas the medium-skill transport sector (tra) has a small employment share of highly-skilled workers. Furthermore, in Great Britain the medium-skill petroleum sector (pet) has a large employment share of highlyskilled workers. Finally, in the Netherlands the medium-skill petroleum (pet) and transport (tra) sectors have large employment shares of highly-skilled workers, whereas the low-skill non-metallic sector (nme) has a large employment share of highly-skilled workers.

Secondly, although the rankings of sectors according to the employment shares of highlyskilled workers are relatively similar across countries, the actual employment shares of intermediate and highly-skilled workers themselves can be very different across countries (see the last two figures in the data appendix). There are particularly striking differences between the employment shares of intermediate-skilled workers in France and those in Germany and Denmark, the countries with by far the largest employment share of intermediate-skilled workers. ${ }^{20}$ The employment shares of highly-skilled workers are largest in Germany and Belgium, and smallest in Spain. The differences between the employment shares of highly-skilled workers in the remaining countries are small (about 0.02 at most).

Furthermore, the last two figures in the data appendix show that between 1988 and 1991 the employment shares of both intermediate and highly-skilled workers increased in almost all countries in the sample. ${ }^{21}$ Apart from Belgium and Germany, the growth rates of the employment shares of intermediate and highly-skilled workers do not differ very much between countries. Belgium exhibits a relatively large growth of highly-skilled workers,

19. See OECD (1986) and Verspagen (1995) for a similar classification with regard to the level of technology, which can be measured by the R\&D intensity (R\&D expenditures relative to production).

20. France has a large number of workers with ISCED-level 2 (lower secondary education) in the manufacturing sectors. Like the ISCED-levels 0 and 1 (pre-primary and primary education), the ISCED-level 2 corresponds with the level of low-skilled labour.

21. The only exceptions are the zero growth rates of the average employment share of highlyskilled workers in France between 1988 and 1989, and of the average employment share of intermediate-skilled workers in Denmark between 1988 and 1991. 
whereas Germany had a relatively large growth of intermediate-skilled workers. ${ }^{22}$

\section{Estimation results}

This section presents the results of estimating the worker and the allocative effect on sectoral productivity levels on the one hand, and the diffusion and the research effect on productivity growth on the other hand. These effects have been discussed in the introduction to this paper, while equations (5) and (9), which have been used to estimate these effects were derived in section 2. As far as possible, my estimates of these equations will be compared with those in other empirical studies. Following these estimation results, some conclusions will be drawn with regard to underinvestment or overinvestment of human capital as indicated by relatively small or relatively large employment shares of intermediate and highly-skilled workers.

The cross-section regression analysis of this paper might break down if the production functions differ between sectors. It would be theoretically preferable to regress the value added per worker in one particular sector on the variables mentioned above. This was not possible since only seven observations were available for each sector. Therefore it is assumed that the differences between the production functions are averaged out in the sample of sectors (see also Davies and Caves, 1987). Moreover, outliers such as the petroleum refineries (pet) and other manufacturing industries (oma) sectors are not included in the sample, since the valued added per worker and capital intensity of these sectors vary widely between countries. The regressions were carried out for a pooled sample of thirteen manufacturing sectors of seven countries.

Table 1 shows the results when least squares regressions are applied to equations (5) and (9) in a dummy variable model (see Judge et al., 1985). ${ }^{23}$ The reference year for equation (5) is either 1988 or 1991 , while equation (9) covers the period between 1988 and $1991 .^{24}$ The first column presents the variables that are incorporated into equations (5) and (9). ${ }^{25}$ The second, third and fourth columns of table 1 show the estimation results of equation (5). The estimated coefficients of intermediate (IS) and highly-skilled (HS) labour indicate the worker and allocative effect. The second and the third columns refer to 1988, whereas the

22. In general the employment shares of intermediate and highly-skilled workers in individual sectors of a particular country are very similar to the average growth in the employment shares across all fifteen manufacturing sectors of that country.

23. Since the coefficients of capital intensity, average firm size and the shares of low, intermediate and highly-skilled labour are constrained as shown by equation (5), non-linear least squares regression is applied to estimate the coefficients of equation (5) directly. Equation (9) is estimated by ordinary least squares regression. The estimations were carried out using the MicroTSP statistical package (version 7.0).

24. See the data appendix for a description of the data sources. The results of the estimations for 1989 and 1990 are available on request from the author.

25. The variable $C$ indicates the constant term. 
fourth column refers to 1991 . Since no data was available for the average firm size ( $\bar{L} 30)$ of the manufacturing sectors of France, these sectors are excluded from the observations of the second column. The third column shows the estimation results when France is included, but the average firm size is excluded as an explanatory variable. The fifth column presents the estimation results of equation (9). The diffusion effect is indicated by the estimated coefficients of $I S^{\star} G A P$ and $H S^{*} G A P$, while the research effect is indicated by the estimated coefficients of IS and HS. The growth in capital intensity and in the employment shares of intermediate and highly-skilled workers are also incorporated in this equation, since these variables would also be expected to influence productivity growth. Moreover, since the model of this paper only analyses the impact of sector-specific variables on sectoral labour productivity (and productivity growth), country-specific dummy variables are incorporated to allow for differences in (the growth rates of) value added per worker between countries.

The results presented in table 1 show that the estimated equations with the level of sectoral labour productivity $(Y / L)$ as the dependent variable perform very well. The adjusted $R$ squared is between 0.75 and 0.78 for the three regressions. The results do not change significantly if the average firm size is excluded from the estimated equation or if the reference year is 1991 instead of 1988. As expected, sectors with a high capital intensity $(K / L)$ reveal a high value added per worker. The coefficient of the capital intensity is significant at the $1 \%$-level, though this coefficient is rather large as compared to the estimates reported in Davies and Caves $(1987)^{26}$ and in Cörvers, De Grip and Orbon $(1995) .^{27}$

Moreover, the estimated coefficient of the average firm size, $\bar{L} 31$, is significantly positive in $1988,{ }^{28}$ which indicates economies of scale at the sector level. An increase in the sector's average firm size of $1 \%$ results in an $8 \%$ increase in labour productivity, which is comparable to the estimates in other empirical studies (Davies and Caves, 1987). ${ }^{29}$ The third column of table 1 shows that the 1988 regression results of equation (5) are little different if average firm size is excluded and the manufacturing sectors of France are included.

26. Davies and Caves estimated output elasticities with respect to physical capital, using gross fixed capital stock per worker as an indicator of capital intensity. These elasticities varied between 0.075 and 0.265 for a sample of British and U.S. industries.

27. This study found estimated coefficients of 0.31 for Germany and 0.40 for the Netherlands, using gross investments in fixed capital per worker as an approximation for capital intensity. The estimated coefficients are smaller, but not significantly smaller, if the stock of physical capital per worker is used as a proxy for the capital intensity.

28. This variable was only available for 1988. This may explain the decreased significance (relative to 1988) of the average firm size in 1991.

29. But note that the distribution of firms with regard to firm size may be more important than the average firm size. 
The table also shows that the employment share of intermediate-skilled workers, IS, does not have a significant effect on the labour productivity of a sector, which implies that the worker and allocative effects are not significant for intermediate-skilled labour. ${ }^{30}$ Moreover, the estimated th 32 is only 0.20 in 1988 and 0.29 in 1991. As pointed out in section 2, these estimates must be compared to the employment shares of intermediate-skilled labour. It can be seen that in the manufacturing sectors the employment shares of intermediate-skilled workers are much larger than 0.20 or 0.29 in Germany and Denmark. ${ }^{31}$ According to equation (6) this implies that the output elasticities with respect to intermediate-skilled labour are negative for the manufacturing sectors in these two countries. Although the evidence is not very strong, because the estimated coefficients are not significant for intermediate-skilled labour and because production functions between sectors and countries may differ, the resulting output elasticities with respect to intermediate-skilled labour may point to overinvestment of human capital in the German and Danish manufacturing sectors. On the other hand, the employment share of intermediate-skilled workers is far below the estimated th 33 in France. ${ }^{32}$ This may point to underinvestment of human capital in French manufacturing sectors due to a small employment share of intermediate-skilled labour in these sectors. Therefore both profits and labour productivity in French manufacturing sectors could be increased by further increasing the employment share of intermediate-skilled labour.

Next, table 1 shows that the estimated th 34 of the employment share of highly-skilled workers, HS, is significantly positive, which indicates a significant worker and allocative effect for this skill group. The estimated coefficients are 0.32 and 0.31 for 1988 and 1991 , respectively, which is much larger than the employment shares of highly-skilled labour of all manufacturing sectors in the sample. The output elasticities with respect to highly-skilled labour, derived from equation (6), are positive for all manufacturing sectors in the sample. Moreover, a large positive difference between the estimated th 35 and the employment share of highly-skilled labour indicates that profits can be maximized by further increasing the employment share of highly-skilled labour. In particular, the employment shares of highly-skilled labour for the low-skill sectors, ${ }^{33}$ and the unweighted average employment shares of highly-skilled labour in the Spanish manufacturing sectors ${ }^{34}$ are far below 0.32 or 0.31 . This points to underinvestment of human capital in these manufacturing sectors due

30. This result may be explained by arguing that intermediate-skilled workers are not productive simply as a result of their initial schooling. If it is assumed that secondary school education and training are complementary, then intermediate-skilled workers may become more productive by training on-the-job or by participating in formal training courses.

31. The 1988 unweighted means of the employment shares of intermediate skilled labour of manufacturing sectors in 1988 were 0.47 and 0.53 for Germany and Denmark, respectively.

32. The unweighted mean of the employment share of intermediate-skilled workers of the manufacturing sectors in France in 1988 is only 0.06 .

33. None of the low-skill manufacturing sectors have employment shares of highly-skilled labour of more than 0.10 .

34. These were 0.05 in 1988 and 0.06 in 1991. 
to a small employment share of highly-skilled workers.

Finally, the coefficients of the country-specific dummy variables (DUM) show the average labour productivity across all 15 sectors is relatively low in Denmark and relatively high in Spain. ${ }^{35}$ These differences cannot be explained by the sector-specific variables incorporated in the equation. Englander and Gurney (1994a) also find a relatively low average labour productivity in Denmark, which they explain by the relative high employment share of part-time workers in Denmark. ${ }^{36}$ Moreover, they find a relatively high average labour productivity in Spain, which they explain by stating that the low employment level in Spain results in a relatively large input of the most productive workers (since these workers are selected first). However there is no evidence for the last hypothesis. Another explanation for the unexpectedly high average labour productivity in Spain may be the relatively high employment share of temporary workers (see Hoevenberg and De Grip, 1994). These workers contribute to the value added of a sector, but may not be counted as employees of that particular sector.

The last column of table 1 shows the estimation results of equation (9) of section 2, in which the growth in the labour productivity of a sector between 1988 and 1991, $d(Y / L) / d t_{88-}$ ${ }_{91}$, is the dependent variable. ${ }^{37}$ Although the estimated equation is significant at the $1 \%$ level, the adjusted $R$-squared is only 0.28 . As could be expected, the coefficient of the growth in capital intensity between 1988 and 1991 is significant (though only at the 10\% level of significance). The estimate of this coefficient is similar to those reported in Englander and Gurney (1994). ${ }^{38}$ However, the estimated coefficients of the growth in the employment shares of intermediate-skilled workers, $d(I S) / d t$, and highly-skilled workers, $d(H S) / d t$, are both negative but not significant.

Table 1

Estimation results for factors explaining sectoral labour productivity (equations 5 and 9)

$\begin{array}{lllll}\text { variable } & (Y / L)_{88} & (Y / L)_{88} & (Y / L)_{91} & d(Y / L) / d t_{88-91}\end{array}$

35. The Netherlands is the reference country, so the dummy variable of the Netherlands has been omitted.

36. See also Hoevenberg and De Grip (1994). However, the Netherlands and Great Britain also have high shares of part-time workers.

37. So far as I have been able to ascertain, no comparable estimates from other empirical studies are available for most of the following estimates.

38. The empirical studies mentioned by Englander and Gurney (1994) show that output growth increases by 0.09 to 0.17 percentage points for every percentage point increase in the investment share. However, these studies explain growth rates of countries by macroeconomic growth models. Moreover, it should be noted that, in the present paper, gross investment in fixed capital per worker is used as an approximation for the capital intensity. 


\begin{tabular}{|c|c|c|c|c|}
\hline$C$ & $\begin{array}{c}6.54 \\
(15.79)^{\mathrm{c}}\end{array}$ & $\begin{array}{c}6.74 \\
(17.70)^{c}\end{array}$ & $\begin{array}{l}7.22 \\
(14.42)^{c}\end{array}$ & $\begin{array}{c}0.03 \\
(1.08)\end{array}$ \\
\hline$K / L$ & $\begin{array}{c}0.46 \\
(11.27)^{\mathrm{c}}\end{array}$ & $\begin{array}{c}0.49 \\
(13.30)^{c}\end{array}$ & $\begin{array}{l}0.43 \\
(9.14)^{c}\end{array}$ & - \\
\hline$d(K / L) / d t$ & - & - & - & $\begin{array}{c}0.12 \\
(1.82)^{\mathrm{a}}\end{array}$ \\
\hline$O 36$ & $\begin{array}{c}0.08 \\
(2.36)^{b}\end{array}$ & - & $\begin{array}{l}0.02 \\
(0.59)\end{array}$ & - \\
\hline$G A P$ & - & - & - & $\begin{array}{c}! \\
!\end{array}$ \\
\hline IS & $\begin{array}{c}0.20 \\
(1.00)\end{array}$ & $\begin{array}{c}0.17 \\
(1.04)\end{array}$ & $\begin{array}{l}0.29 \\
(1.53)\end{array}$ & 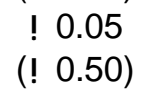 \\
\hline$I S^{*} G A P$ & - & - & . & $\begin{array}{c}0.19 \\
(1.85)^{\mathrm{a}}\end{array}$ \\
\hline$d(I S) / d t$ & - & - & - & 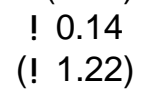 \\
\hline$H S$ & $\begin{array}{l}0.32 \\
(2.96)^{c}\end{array}$ & $\begin{array}{c}0.35 \\
(4.09)^{\mathrm{c}}\end{array}$ & $\begin{array}{l}0.31 \\
(2.91)^{c}\end{array}$ & 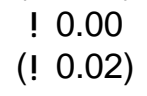 \\
\hline$H S^{\star} G A P$ & - & - & - & $\begin{array}{c}0.07 \\
(0.40)\end{array}$ \\
\hline$d(H S) / d t$ & - & - & - & $\begin{array}{c}\text { ! } 0.10 \\
(! \\
(! .52)\end{array}$ \\
\hline$D U M B E L$ & 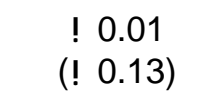 & $\begin{array}{c}! \\
\vdots \\
(! \\
(1.08)\end{array}$ & $\begin{array}{l}! \\
(! 0.07 \\
(! 0.65)\end{array}$ & $\begin{array}{c}0.02 \\
(1.16)\end{array}$ \\
\hline DUMDEU & 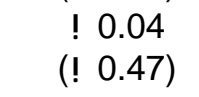 & $\begin{array}{c}0.04 \\
(0.51)\end{array}$ & 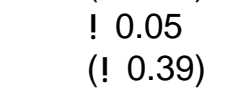 & $\begin{array}{c}0.01 \\
(! 0.34)\end{array}$ \\
\hline DUMDNK & $\begin{array}{c}! 0.25 \\
(! 2.58)^{b}\end{array}$ & $\begin{array}{c}\text { ! } 0.24 \\
(! 2.64)^{b}\end{array}$ & $\begin{array}{l}! 0.41 \\
(! 4.25)^{\mathrm{c}}\end{array}$ & $\begin{array}{c}! 0.09 \\
(! 2.79)^{\mathrm{c}}\end{array}$ \\
\hline DUMESP & $\begin{array}{c}0.47 \\
(4.05)^{\mathrm{c}}\end{array}$ & $\begin{array}{c}0.41 \\
(3.82)^{c}\end{array}$ & $\begin{array}{l}0.28 \\
(2.34)^{b}\end{array}$ & $\begin{array}{c}! \\
(! 2.04 \\
(! 2.04)^{b}\end{array}$ \\
\hline DUMFRA & - & $\begin{array}{c}0.05 \\
(0.49)\end{array}$ & - & 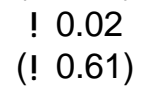 \\
\hline DUMGBR & $\begin{array}{c}0.10 \\
(0.89)\end{array}$ & $\begin{array}{c}0.06 \\
(0.34)\end{array}$ & $\begin{array}{l}0.17 \\
(1.35)\end{array}$ & $\begin{array}{c}0.02 \\
(0.80)\end{array}$ \\
\hline ov 37 & 0.78 & 0.77 & 0.75 & 0.28 \\
\hline F-stat & $29.71^{c}$ & $34.11^{\mathrm{C}}$ & $26.54^{\mathrm{C}} 3.45^{\mathrm{c}}$ & \\
\hline$n$ & 76 & 88 & 76 & 89 \\
\hline
\end{tabular}

Note: the superscripts $a, b$ and $c$ indicate a significant coefficient at the $10 \%, 5 \%$ and $1 \%$ level, respectively. T-statistics appear in parentheses beneath the coefficients.

The coefficient which indicates the diffusion effect of intermediate-skilled workers, IS ${ }^{*} G A P$, is significant. An increase of 1 percentage point in the $I S^{*} G A P$ leads to an increase of 0.19 percentage points in the growth in sectoral labour productivity. The coefficient of the variable indicating the research effect of intermediate-skilled workers, IS, is not significant, and its sign is unexpected. Furthermore, none of the variables related to the employment share of highly-skilled workers are significant.

The coefficient for the technological gap $(G A P)$, which is calculated by considering the 13 
differences in value added in the same sector in different countries, is not significant. However its negative sign indicates that the labour productivity of sectors diverged between 1988 and 1991, since the larger the gap, the lower the growth in labour productivity.

The estimated coefficient of $H S^{*} G A P$, indicating the diffusion effect, is positive but not significant. The estimated coefficient of $H S$ is not significant and its sign is unexpected. These results imply that neither the diffusion effect nor the research effect of highly-skilled labour can be confirmed.

\section{Conclusions}

This paper discusses four effects of human capital on the labour productivity of manufacturing sectors. Since sectoral labour productivity can be regarded as an indicator of competitiveness, the paper implicitly examines the importance of investments in human capital for increasing the international competitiveness of manufacturing sectors within the EU Member States. It has been argued that the worker and allocative effects of human capital increase the productivity level, whereas the diffusion and research effects of human capital increase productivity growth. Human capital is measured by the employment shares of intermediate and highly-skilled workers. Other variables that are relevant in explaining labour productivity at sector level are the capital intensity and average firm size. Using a Cobb-Douglas function for the effective labour input of intermediate and highly-skilled workers, it has been shown that, if the employment shares of intermediate or highly-skilled workers produce a large worker and allocative effect, this indicates that both profits and labour productivity could be increased by raising the employment share of these workers.

The data described here reveals that the sector rankings by the employment shares of highly-skilled workers are relatively similar across the seven countries in the sample. There is less congruence between the rankings with regard to the employment shares of intermediate-skilled workers. The fifteen manufacturing sectors distinguished in this paper can be divided into three groups of sectors with different employment shares of highlyskilled workers: low-skill sectors, medium-skill sectors and high-skill sectors. Despite the relatively similar rank orders of manufacturing sectors across countries, the sectoral employment shares of intermediate and highly-skilled workers can differ very much between countries.

Least squares estimations for thirteen manufacturing sectors of the sample countries showed that capital intensity and average firm size have a significantly positive effect on labour productivity at sector level. The effects of intermediate and highly-skilled labour on sectoral labour productivity, which reflect the worker and allocative effect, are also positive. Moreover, the employment shares of intermediate-skilled workers in Germany and Denmark are large relative to the estimated worker and allocative effect of intermediateskilled workers, whereas in France the employment share of intermediate-skilled workers is relatively small. Although the worker and allocative effect is not significant for intermediate- 
skilled labour, the results may indicate overinvestment of human capital in the German and Danish manufacturing sectors, and underinvestment of human capital in the French manufacturing sectors.

The worker and allocative effect of highly-skilled labour is significantly positive. The employment shares of highly-skilled labour are small relative to the estimated worker and allocative effect in the low-skill manufacturing sectors of all countries in the sample, and in all the Spanish manufacturing sectors. This indicates underinvestment in human capital in these manufacturing sectors. However, the sectors may have different production functions, and thus different optimal inputs of intermediate and highly-skilled labour.

Both capital intensity growth and the employment share of intermediate-skilled labour have a significant positive effect on the growth in labour productivity. The results imply that the employment share of intermediate-skilled workers has a diffusion effect on labour productivity, since it reduces the technological gap, within a sector, between the various countries. A static analysis comparing estimated coefficients for the worker and allocative effect with the employment shares of intermediate-skilled workers does not account for such dynamic implications with regard to productivity growth. Therefore the diffusion effect of intermediate-skilled labour on productivity growth casts some doubt on the apparent overinvestment of intermediate-skilled labour in German and Danish manufacturing sectors. On the other hand, the diffusion effect of intermediate-skilled labour provides additional evidence that the employment share of intermediate-skilled workers in French manufacturing sectors is too small. No diffusion effect could be shown for the employment share of highly-skilled workers, and there was no evidence to support a research effect from the employment shares of intermediate and highly-skilled workers.

\section{References}

Bartel, A.P. and F.R. Lichtenberg (1987), The Comparative Advantage of Implementing New Technology, Review of Economics and Statistics, Vol. 69, No. 1, pp. 1-11.

Balassa, B. (1963), An Empirical Demonstration of Classical Comparative Cost Theory, Review of Economics and Statistics, Vol. 45, pp. 231-238.

Bowles, S. (1970), Aggregation of Labour Inputs in the Economics of Growth and Planning. pp. 68-81.

Experiments with a Two Level CES Function, Journal of Political Economy, Vol. 78,

Cörvers, F. (1994), Human Capital Factors at the Firm Level, Working Paper 7E, Research Centre for $\quad$ Education and the Labour Market, Maastricht.

Cörvers, F., A. de Grip and J.P. Orbon (1995), Concurrentiekracht, produktiviteit en human capital: een vergelijking tussen Nederland en Duitsland, Maandschrift Economie, Vol. 59, pp. 221-241.

Davies, S.W. and R.E. Caves (1987), Britain's Productivity Gap, National Institute of Economic and Social Research, Cambridge University Press, Cambridge, etc.

Dornbush, R., S. Fisher and P.A. Samuelson (1977), Comparative Advantage, Trade, and Payments in a Ricardian Model with a Continuum of Goods, American Economic Review, Vol. 
67, pp. 823-839.

Englander, A.S. and A. Gurney (1994), Medium Determinants of OECD Productivity, OECD Economic Studies, No. 22, pp. 49-109.

Englander, A.S. and A. Gurney (1994a), OECD Productivity Growth: Medium-Term Trends, OECD Economic Studies, No. 22, pp. 111-154.

European Commission (1994), Growth, Competitiveness and Employment: The challenges and ways forward into the 21st century, White Paper, Brussels and Luxembourg.

Fallon, P.R. (1987), Labour Quality and Education, in: Psacharopoulos, G. (ed.), Economics of Education: Research and Studies, Pergamon Press, Oxford, pp. 116-121.

Francis, A. and P.K.M. Tharakan (1989, eds), The Competitiveness of European Industry, Routledge, London, New York.

Grossman G.M. and E. Helpman (1992), Innovation and Growth in the Global Economy, second printing, MIT Press, Cambridge, etc.

Hartog, J. (1992), Capabilities, Allocation and Earnings, Kluwer Academic, Norwell, Mass. and Dordrecht.

Hoevenberg, J. and A. de Grip (1994), Indicators of Occupational Employment in the European Union, Report ROA-R-1994/3E, Research Centre for Education and the Labour Market, Maastricht.

Judge, G.G., W.E. Griffiths, R.C. Hill, H. Lütkepohl and T. Lee (1985), The Theory and Practice of Econometrics, second edition, Wiley, New York, etc.

MacDougall, G.D.A. (1951), British and American Exports: A Study Suggested by the Theory of Comparative Costs, Economic Journal, Vol. 61, pp. 697-724.

Nelson, R.R. and E.S. Phelps (1966), Investment in Humans, Technological Diffusion and Economic Growth, American Economic Review Papers and Proceedings, Vol. 56, pp. 69-75.

Niosi, J. (1991, ed.), Technology and National Competitiveness, McGill-Queen's University Press, Montreal \& Kingston.

OECD (1986), R\&D, Invention and Competitiveness, Science and Technology Indicators, No. 2.

Pencavel, J. (1991), Higher Education, Productivity, and Earnings: A Review, Journal of Economic Education, Vol. 22, pp. 331-359.

Porter, M. (1990), The Competitive Advantage of Nations, MacMillan, London.

Ram, R. (1980), Role of Education in Production: A Slightly New Approach, Quarterly Journal of Economics, Vol. 94, pp. 365-373.

Romer, P.M. (1990), Endogenous Technological Change, Journal of Political Economy, Vol. 98, pp.71- 102.

Verspagen, B. (1992), Uneven Growth between Interdependent Economies, University of Limburg, Dissertation no. 92-10, UPM, Maastricht.

Verspagen, B. (1995), R\&D and Productivity: A Broad Cross-Section Cross-Country Look, Journal of Productivity Analysis, Vol. 6, pp. 117-135.

Welch, F. (1970), Education in production, Journal of Political Economy, Vol. 78, pp. 35-59. 


\section{Data Appendix}

\section{Employment shares of low, intermediate and highly-skilled labour}

The data for calculating these employment shares was drawn from Eurostat's Labour Force Survey (1988 -1991). The classification of the skill level is analogous to UNESCO's International Standard Classification of Education (ISCED). ISCED levels 0/1 (pre-primary and primary education) and 2 (lower secondary education) correspond to the skill level of low-skilled labour. ISCED level 3 (higher secondary education) corresponds to the skill level of intermediate-skilled labour, and ISCED levels 5 to 7 (higher university and non-university education) corresponds with the skill level of highly-skilled labour. The numbers of workers in the various $\mathrm{NACE}^{39}$ classes (at the 2-digit level) have been aggregated to $\mathrm{ISIC}^{40}$ sectors according to the concordance table listed below. The numbers of intermediate or highlyskilled workers in the NACE classes which are below the threshold value of Eurostat are estimated using the number of intermediate and highly-skilled workers in the NACE divisions (at the 1-digit level). Since there was no data available for France in 1990 and 1991, the employment shares of 1989 have been used as an approximation for 1990 and 1991. Conversely, since there was no data available for the Netherlands in 1988 and 1989 , the employment shares of 1990 have been used as an approximation for 1988 and 1989 .

\section{Sectoral labour productivity}

The variable indicating the average labour productivity per worker in a sector has been calculated by dividing the value added per sector by the number of workers employed per sector. Data on both the value added and the numbers of workers employed was drawn from the STAN industrial database. The STAN database expresses value added in local currencies at current prices. Therefore these values have been converted into 1985 prices using sector prices from the United Nations Industrial Statistics (UNIDO) database. Purchasing power parities based on GDP figures, and drawn from the Penn World Tables, have then been used to convert the local currencies into 1985 dollar prices. For Spain, the value added per worker in 1990 is used as an approximation for the value added per worker in 1991.

\section{Capital intensity}

The capital intensity variable has been approximated by gross investments in fixed capital per worker. Data on gross investments in fixed capital and the number of workers employed was drawn from the STAN industrial database. Since investments are expressed in local currencies at current prices, these values have been converted into 1985 prices

39. General Industrial Classification of Economic Activities, which is used within the European Union.

40. International Standard Industrial Classification of the United Nations, which is used for the classification of sectors in the STAN database (see below). 
using sector prices from the United Nations Industrial Statistics (UNIDO) database. Purchasing power parities of gross investments, drawn from the Penn World Tables, have then been used to convert the local currencies into 1985 dollar prices. For Spain, the capital intensity in 1990 is used as an approximation for the capital intensity in 1991.

\section{Average firm size}

The data on the number of establishments in each sector was drawn from the Industrial Structure Statistics (ISS) of the OECD. For most countries data was only available up to 1988. The average firm size has been calculated by dividing the number of establishments by the number of workers employed. The latter data was drawn from the STAN industrial database. For France, no data was available for the number of establishments per sector.

\section{Technological gap}

The variable indicating the technological gap in a particular sector, between various countries, is measured using data on the value added per worker. The definition provided in section 2, GAP $=(T(t) ! A(t)) / A(t)$, is used to calculate the technological gap. The level of technological knowledge actually in use in a sector $(A(t))$ is assumed to be represented by the value added per worker for that particular sector. Moreover, it is assumed that the level of theoretical technological knowledge $(T(t))$ is represented by the highest labour productivity, for that particular sector, within the sample of seven countries. For example, the technological gap of the food sector in France is approximated by the difference between the labour productivity of the food sector in the sample country which has the highest food sector labour productivity and the productivity of the food sector in France, divided by the productivity of the food sector in France.

\section{Classification of ISIC sectors}

$\begin{array}{lll}\text { foo } & 3100 & \text { Food, beverages and tobacco } \\ \text { tex } & 3200 & \text { Textile, wearing apparel and leather industries } \\ \text { woo } & 3300 & \text { Wood and wood products, including furniture } \\ \text { pap } & 3400 & \text { Paper and paper products, printing and publishing } \\ \text { che } & 3510+20 & \text { Industrial chemicals and other chemical products } \\ \text { pet } & 3530+40 & \text { Petroleum refineries and miscellaneous products of petroleum and coal } \\ \text { rup } & 3550+60 & \text { Rubber products and plastic products not elsewhere classified } \\ \text { nme } & 3600 & \text { Non-metallic mineral products, except products of petroleum and coal } \\ \text { bmi } & 3710+20 & \text { Iron and steel basic industries and non-ferrous metal basic industries } \\ \text { pme } & 3810 & \text { Fabricated metal products, except machinery and equipment } \\ \text { mac } & 3820 & \text { Machinery except electrical } \\ \text { ele } & 3830 & \text { Electrical machinery apparatus, appliances and supplies } \\ \text { tra } & 3840 & \text { Transport equipment } \\ \text { opt } & 3850 & \text { Professional, scientific, measuring, controlling equipment not elsewhere } \\ & & \text { classified, photographic and optical goods }\end{array}$


oma $3900 \quad$ Other manufacturing industries

Table of concordances between ISIC 1977 (rev. 2) and NACE 1970 classifications

\begin{tabular}{|c|c|c|}
\hline Abbreviation & ISIC 1977 & NACE 1970 \\
\hline foo & 3100 & $41+42$ \\
\hline tex & 3200 & $43+44+45$ \\
\hline woo & 3300 & 46 \\
\hline pap & 3400 & 47 \\
\hline che & $3510+3520$ & $25+26$ \\
\hline pet & $3530+3540$ & $11+12+13+14+15+21+23$ \\
\hline rup & $3550+3560$ & 48 \\
\hline nme & 3600 & 24 \\
\hline bmi & $3710+3720$ & 22 \\
\hline pme & 3810 & 31 \\
\hline mac & 3820 & $32+33$ \\
\hline ele & 3830 & 34 \\
\hline tra & 3840 & $35+36$ \\
\hline opt & 3850 & 37 \\
\hline oma & 3900 & 49 \\
\hline
\end{tabular}




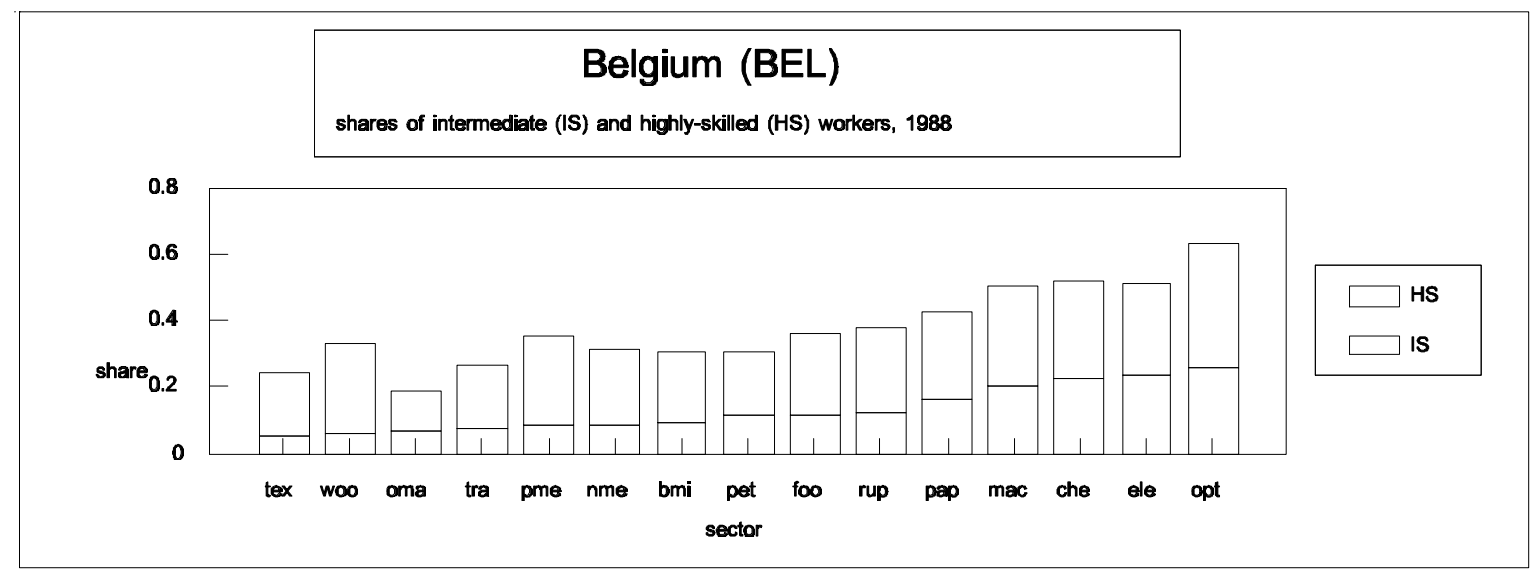

Figures
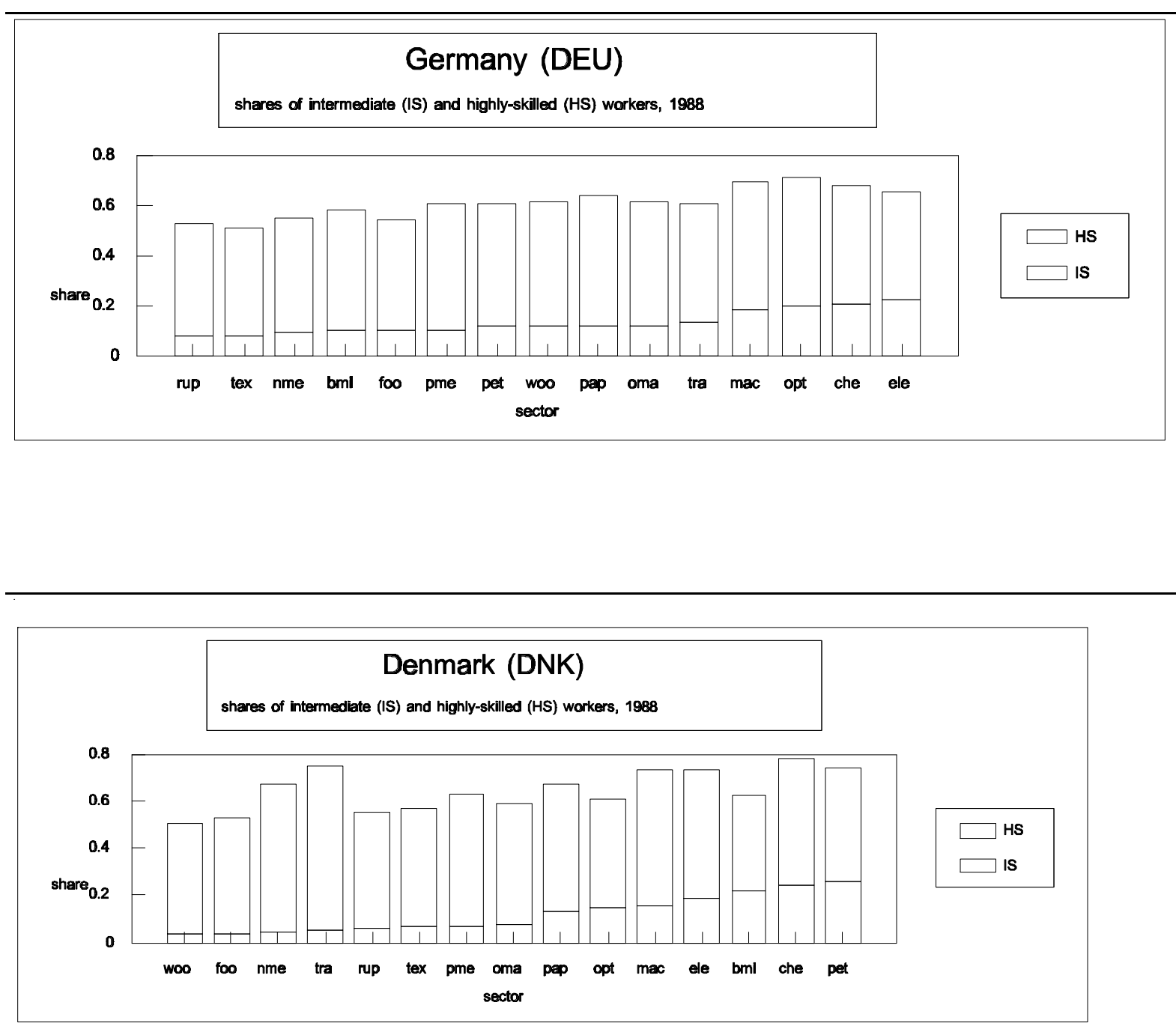

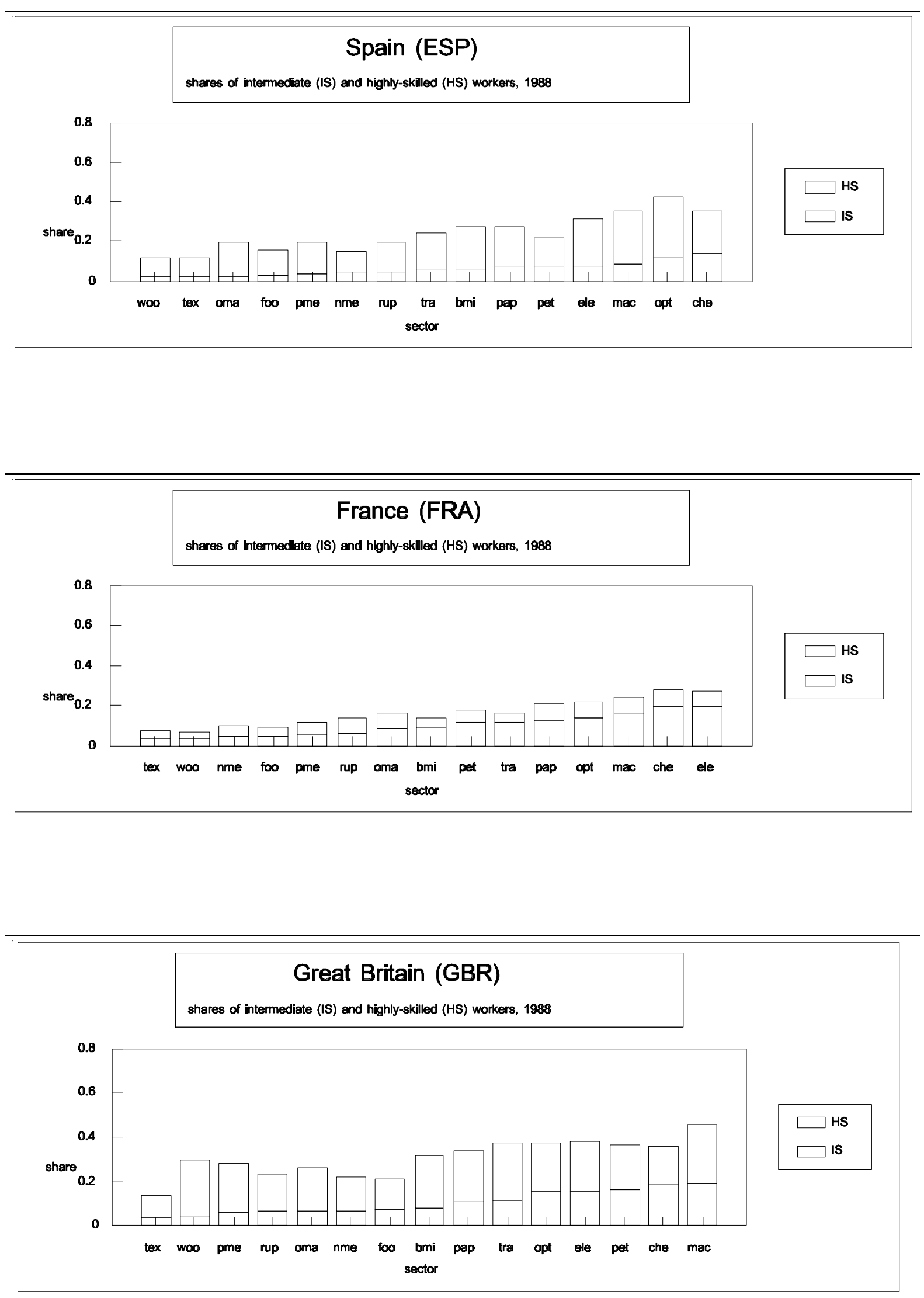

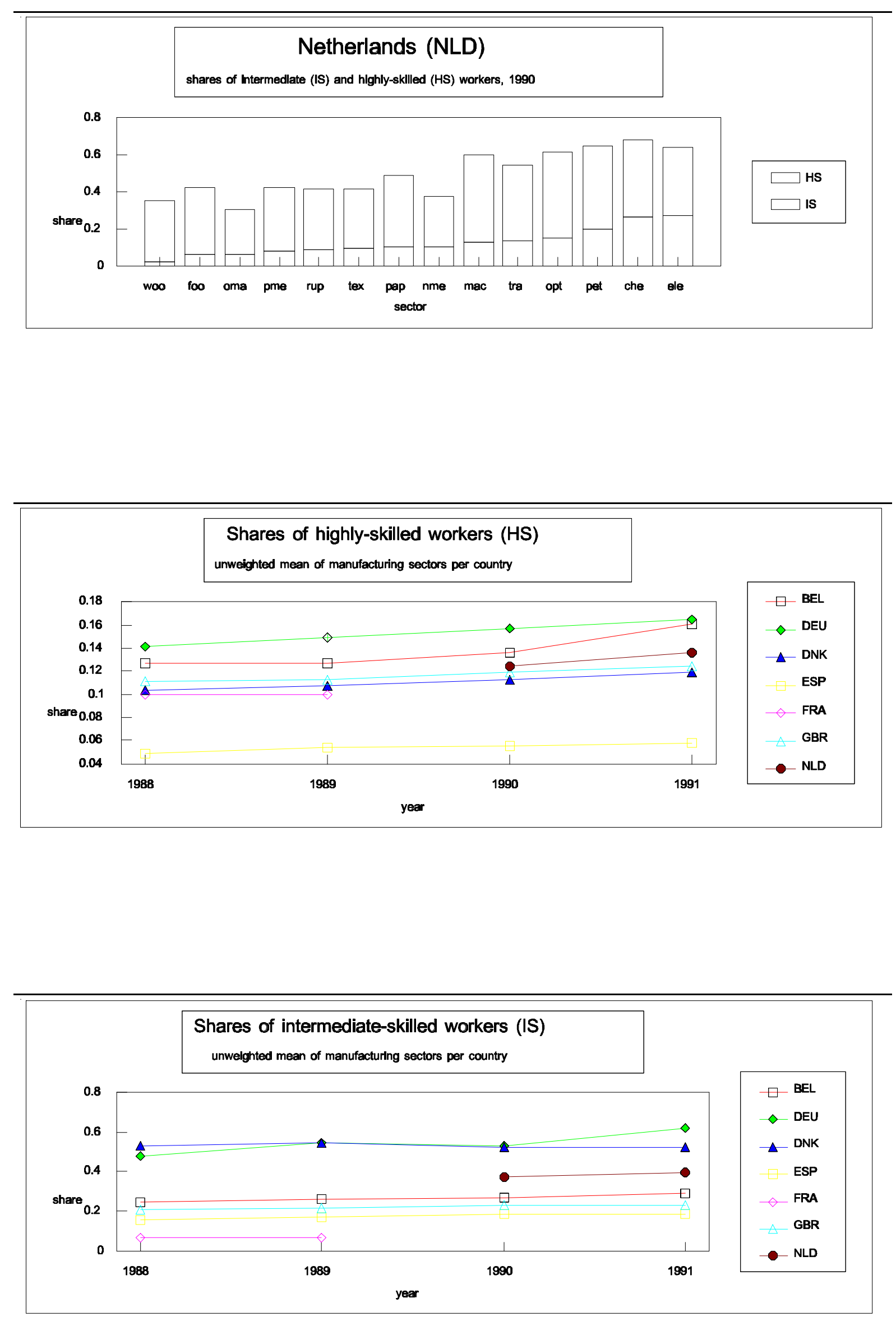